\title{
A new species of Chlorota Burmeister (Melolonthidae: Rutelinae: Rutelini) from Cerrado and Amazon biomes transition
}

\author{
Rone Andrews Freitas Medeiros ${ }^{1,2}$ \& Paschoal Coelho Grossi ${ }^{1,3}$ \\ 1 Universidade Federal Rural de Pernambuco (UFRPE), Departamento de Agronomia (DEPA), Laboratório de Taxonomia de Insetos, \\ Programa de Pós-Graduação em Entomologia Agrícola. Recife, PE, Brasil. \\ 2 ORCID: http://orcid.org/0000-0002-7059-1622. E-mail: roneagrouf@@gmail.com (corresponding author) \\ ${ }^{3}$ ORCID: http://orcid.org/0000-0001-6601-5967. E-mail: paschoal.grossi@gmail.com
}

\begin{abstract}
Chlorota cleidecostae sp. nov. is described based on a unique female collected at Maranhão State, Carolina municipality, in the "Meio Norte" region, a biotope comprising Cerrado, Caatinga and Amazon biomes. The new species is distinguished from all other Chlorota species by having the striped elytral pattern with red costae, and surface of pronotum dull, dark, metallic, and smooth. An updated map and a key for species and subspecies that occur in Brazil are also presented.
\end{abstract}

Key-Words. Anticheirina; Distribution; Maranhão; Neotropical region; Taxonomy.

\section{INTRODUCTION}

The Neotropical subtribe Anticheirina (Melolonthidae: Rutelinae: Rutelini) comprises 44 genera and about 550 species (Moore et al., 2014), distributed mainly in Central America, West Indies and Amazon. Among these, the genus Chlorota Burmeister, 1844 is composed of 38 described species (Soula, 2005, 2006, 2008; Krajcik, 2008). There are six species, and four subspecies of Chlorota distributed throughout Brazil: Chlorota abdominalis Ohaus, 1926; Chlorota aulica Burmeister, 1844; Chlorota cuprea Burmeister, 1844; Chlorota espiritosantensis Ohaus, 1912; Chlorota haemorrhoidalis solimoensis Ohaus, 1908; Chlorota haemorrhoidalis touzoti Soula, 2002; Chlorota parensis Soula, 2002; Chlorota paulistana Ohaus, 1912; Chlorota surinama egana Soula, 2002; Chlorota surinama lemoulti Soula, 2002. Soula (2002a) proposed four species groups within the genus: aulica, caucana, limbaticollis, and terminata. The genus is characterized by the usually large body shape, with outer margin of mandibles toothed or sinuous; scutellum short, clearly wider than long or almost so; and mesosternal process short and bent downwards (Soula, 2002a, b).

In the present contribution, we describe a remarkable new species of Chlorota of the aulica group, C. cleidecostae sp. nov., from Brazil. We also present a map with updated known distribution for species and subspecies found in Brazil (Fig. 1), and a key to the Brazilian taxa.

\section{MATERIAL AND METHODS}

Specimens were examined from the collections: Coleção Entomológica da Universidade Federal Rural de Pernambuco, Recife, Brazil (CERPE) and Muséum National d'Histoire Naturelle, Paris, France (MNHN) (examined through images); and the new species was deposited on CERPE.

Transcription of the labels follows: quotation marks (" ") at the beginning and the end of the information present on the label(s) of the specimen examined; "/" change of line on the same label; labels were sequentially numbered.

Photographs were taken with a digital camera Nikon D5300 attached to a Zeiss 508 DOC stereomicroscope, and a Nikon D90 with $40 \mathrm{~mm}$ macro lens with aid of the software Helicon Remote. Images were processed with the software Combine ZP. A digital caliper was used for measurements.

The map was made with the software Google Earth Pro ${ }^{\circledR}$, GPS points has been collected based on literature, and specimens' labels, then exported to the site www.simplemappr.net (Shorthouse, 2010). When the locality data on the label were insufficient, the city hall of the locale on the label was used. New distribution data are presented for Chlorota cuprea Burmeister, 1844 and Chlorota haemorrhoidalis touzoti Soula, 2002.

The terminology used follows Jameson (1990) and Grossi \& Vaz-de-Mello (2015). 


\section{RESULTS}

\section{Chlorota cleidecostae sp. nov.}

(Figs. 2A-C)

Type material: HOLOTYPE $\&$ (CERPE), labels: 1) "Brasil, Maranhão, Carolina PARNA Chapada das Mesas, Ribeirão Estiva, 04-27.i.2014, armadilha suspensa, F.L. de Oliveira leg.".

Diagnosis: Clypeus and frons densely punctate; apex of clypeus apex weakly acuminate; pre-mentum weakly emarginated at apex; pronotum with obsolete puncture, almost smooth; elytral interstriae with moderate deep puncture, interstriae with orange color; mesotibiae with two carinae; metatibiae with one carina; inner mesothoracic spur with one ventral carina; spurs of metathoracic legs with one ventral carina each.

\section{Description}

Female holotype, here designated: Total length $22.30 \mathrm{~mm}$. Total width across humeri $11.35 \mathrm{~mm}$, across elytral middle $11.75 \mathrm{~mm}$.

Body: Shape ellipsoidal, dorsal surface convex, glabrous, venter almost flat, densely setose.

Color: Reddish-brown, shiny; elytra with orange longitudinal costae.

Head: Clypeus parabolic, apex weakly acuminate; surface densely punctate; punctures large, deep; frons with anterior puncture larger than medial and posterior punctures; vertex apparently smooth. Labrum bilobed, weakly emarginated, lobes with apical sulcus and a row of setae. Mandibles with rounded apex and outer sides weakly lobed. Last labial palpomere with truncate apex, and elliptical sensorial area on dorsal view; pre-mentum apex weakly emarginate. Antennae with 10 antennomeres, club about 1.3 times longer than antennomeres II-VII combined; dorsal area of scape with few, large, sparse punctures; pedicel subcylindrical, antennomere III subrectangular, IV-V subquadrate, VI-VII subconical.

Thorax: Anterior angles of pronotum rounded, posterior angles almost straight; disc convex, moderately punctured; punctures obsolete and more evident near anterior and posterior angles. Scutellum as long as wide, subtriangular, anterior margin straight, surface sparsely punctured.

Elytra: Length about 1.1 times longer than wider; surface with 10 elytral punctured interstriae (Fig. 2A); punctures moderate to large, deep, rounded to oblong, sometimes coalescent; interstriae almost smooth; odd interstriae dark orange; interstriae VII-VIII anteriorly incomplete and fused to each other near apex. Elytral surface just above epipleuron with a wide row of dense punctures at base, posterior punctures sparser than anterior punctures.

Venter: Mesosternal process subtriangular, apex glabrous, smooth, and rounded, obscured in lateral view; discrimen marked by a weak longitudinal line, not forked.

Abdomen: Sternites III-VI distinctly wrinkled at apex and with an anterior row of setose punctures, row interrupted at middle; sternite VII transversely wrinkled and with scattered posterior setae near apex (Fig. 2B); sternite VIII rugopunctate, covered by small to long setae. Pygidium with strong wrinkles, apex with dense, medium-sized setae; small setae sparsely distributed in anterior and medial areas.

Legs: Metafemur strongly widened, more than two times wider than mesofemur (Fig. 2C), anterior margin convex, posterior margin moderately emarginated. Protibiae with three outer teeth, spur with $1.5 \mathrm{~mm}$ in length, $0.3 \mathrm{~mm}$ in width (Fig. 2A); mesotibiae with two transversal carinae, metatibiae with one transversal carina; inner spur of mesotibiae with one ventral carina, and each metatibial spur with one ventral carina.

\section{Male: Unknown.}

Etymology: We dedicate the new species to Professor Cleide Costa as a recognition of her tremendous work on Coleoptera systematics and friendship to the second author of this paper.

Remarks: The unique specimen of $C$. cleidecostae sp. nov. was collected in a suspended trap in canopy. This is also the first time that a Chlorota species was collected in Maranhão state (new state record) (Fig. 1). Furthermore, this is the first species within the genus with elytral pattern with orange interstriae.

\section{DISCUSSION}

Chlorota cleidecostae sp. nov. is found in the central region of Brazil, filling a gap that existed between the previously described species, present in the northern region, northeast and southeast regions (Soula, 2002b). The biome of the region is Cerrado, and the specimen was found on Chapada das Mesas National Park, Maranhão state (Fig. 1).

The new species is similar to C. tristis (Fig. 2D), and both species have dark coloring; clypeus parabolic with apex acuminate; elytral pattern with elytral disc and interstriae deeply punctate, elytral interstriae smooth and carinate; small scutellum and mesoventral process; and venter moderately setose. Chlorota cleidecostae sp. nov. is identified by the pronotum almost smooth; elytra reddish-brown and with orange longitudinal costae; and scutellum as long as wide; $C$. tristis have pronotum densely and finely punctate; violet brown elytra with black interstriae; and scutellum wider than long (Fig. 2D). 


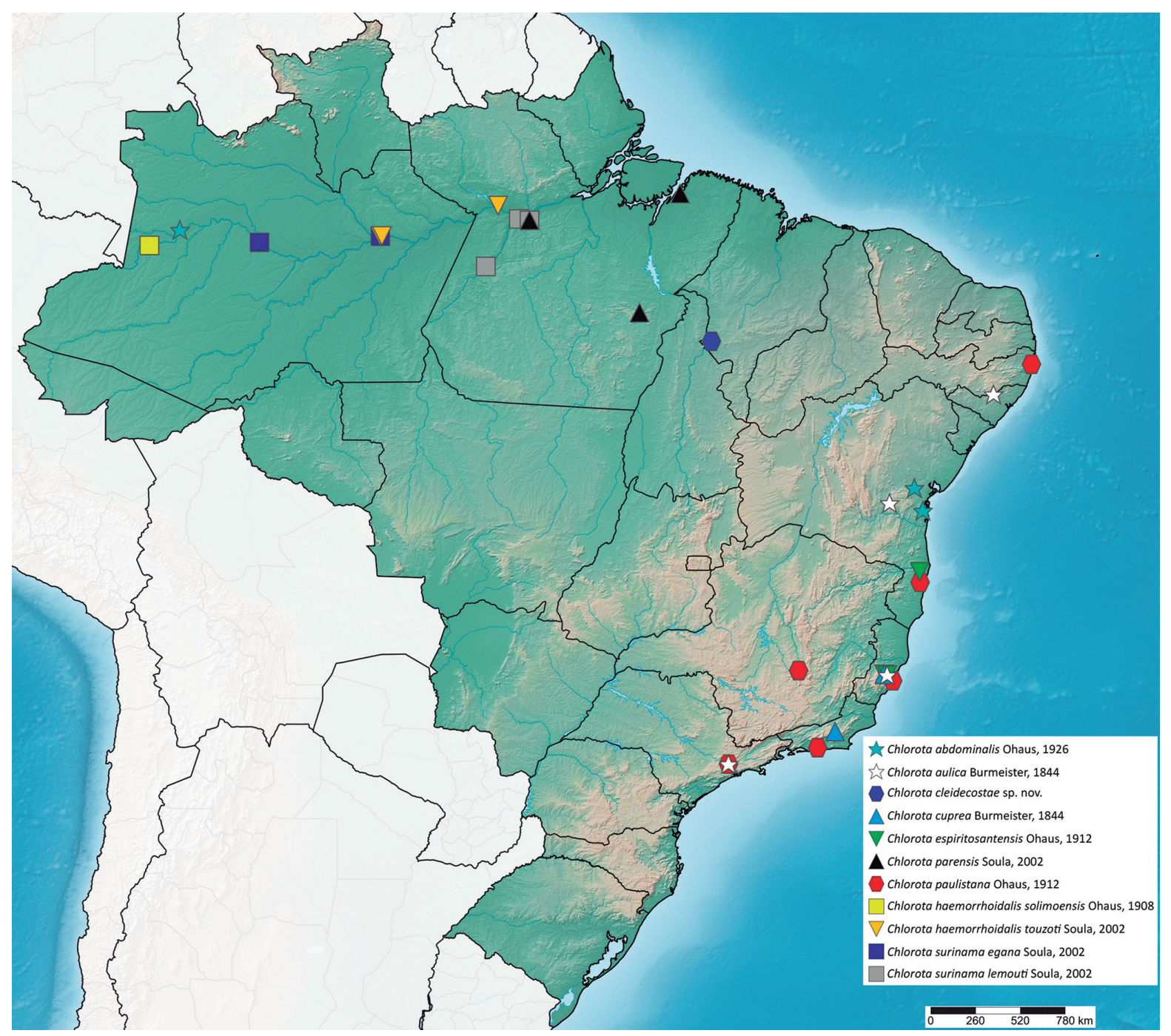

Figure 1. Geographical distribution of Chlorota species and subspecies in Brazil.

\section{Synopsis of the distribution of Chlorota in Brazil}

In Brazil two Chlorota groups are recorded, aulica group (Figs. 2D, 3A-F) with C. aulica and C. cuprea; and terminata group (Figs. 4A-F, 5A-D) with C. abdominalis, C. cleidecostae, C. espiritosantensis, C. haemorrhoidalis solimoensis, C. haemorrhoidalis touzoti (Figs. 4A-C), C. parensis (Fig. 5D), C. paulistana (Figs. 4D-F), C. surinama egana (Fig. 5C), C. surinama lemoulti (Fig. 5B).

Chlorota abdominalis is recorded in Amazonas state near the basin of the Madeira and Solimões Rivers, near Manaus municipality, and Bahia state on Ituberá and Santa Terezinha (Serra da Jiboia) municipalities, in fragments of the Atlantic Forest biome (Soula, 2002b; Ferreira et al., 2018).

Chlorota aulica presents uniform greenish color with green-metallic reflections (Figs. 3A-C). This species was originally described from Guyana, and is distributed mainly in Brazilian Atlantic Forest, from Pernambuco to São Paulo states (Soula, 2002b). The records for Guyana consist only of historical material, which could be probably mislabeled specimens. Despite being cited as distributed in many countries in Central and South America
(Ferreira et al., 2018), the only published records for this species are from Guyana and Brazil.

Chlorota cuprea is very similar to C. aulica, which can be diagnosed by the coloration with more copper reflexes than the former (Figs. 3D-F), and apex of mesosternal process suboval (Fig. 3E). As C. aulica, it is known from Atlantic Forest only, but occurs in highest elevations like Serra da Mantiqueira, Serra do Mar and Serra dos Órgãos (Soula, 2002b).

Chlorota espiritosantensis has lighter elytral color than other species of this group. It is mainly found in Espírito Santo and Bahia states, above Doce River basin, and within Atlantic Forest Biome (Soula, 2002b).

Chlorota paulistana presents head, pronotum and scutellum with green color, and reflexes, without lighter elytral suture coloration. It can be found in Southeast and Northeast Regions, ranging from Pernambuco to São Paulo states, all located within Atlantic Forest Biome (Soula, 2002b; Ferreira et al., 2018; Carvalho et al., 2019).

The subspecies Chlorota haemorrhoidalis solimoensis and C. surinama egana Soula occur in Amazonas state, and C. surinama lemoulti and C. haemorrhoidalis touzoti in Pará state. 

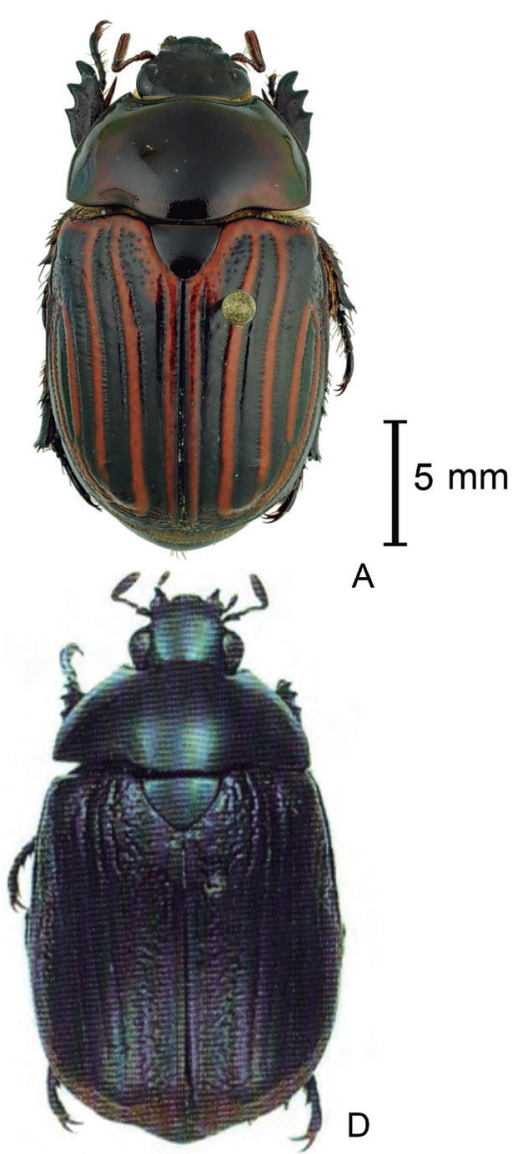

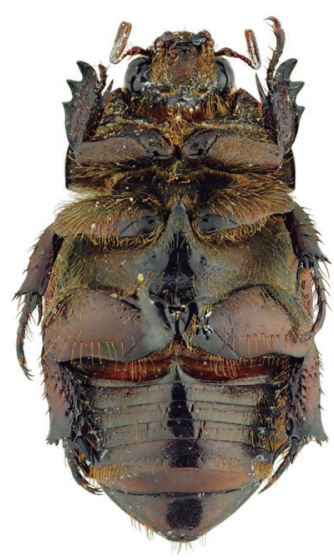

B

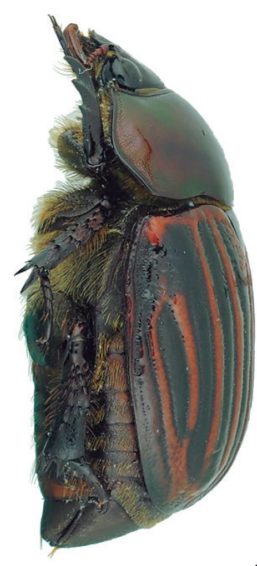

C

Figure 2. Chlorota species, habitus. (A-C) Female holotype of Chlorota cleidecostae sp. nov. (dorsal, ventral, lateral); (D) Holotype of Chlorota tristis Arrow, 1900 (image from Soula, 2002a).
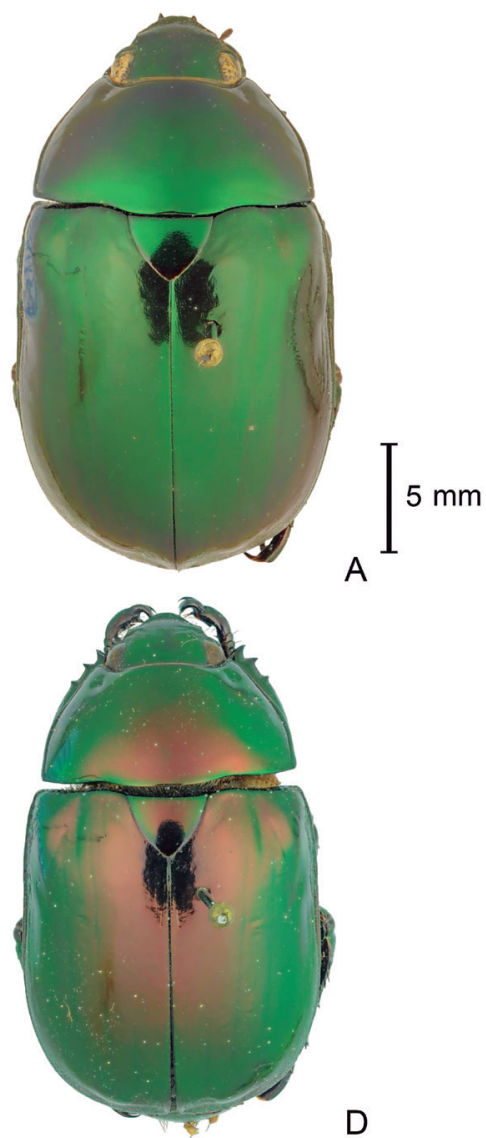
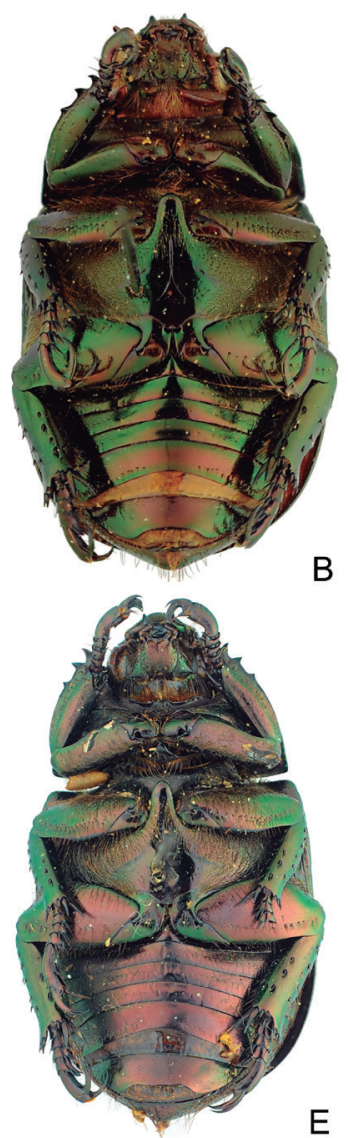
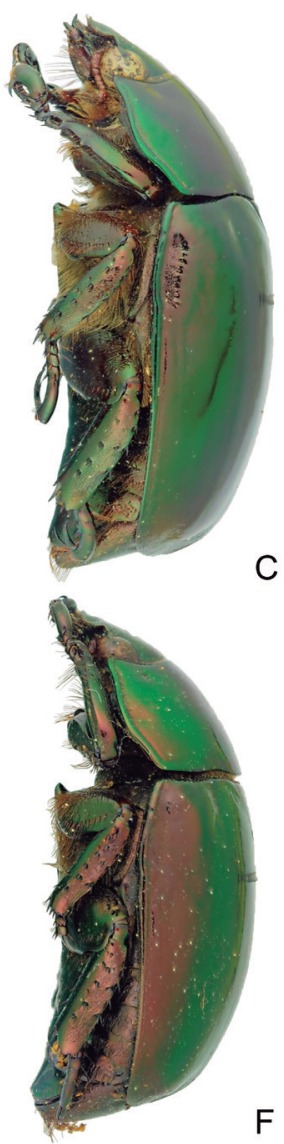

Figure 3. Chlorota species, habitus. (A-C) C. aulica Burmeister, 1844 (dorsal, ventral, lateral); (D-F) C. cuprea Burmeister, 1844 (dorsal, ventral, lateral). 


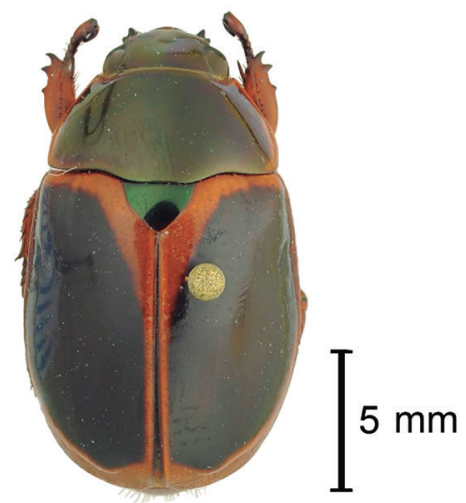

A

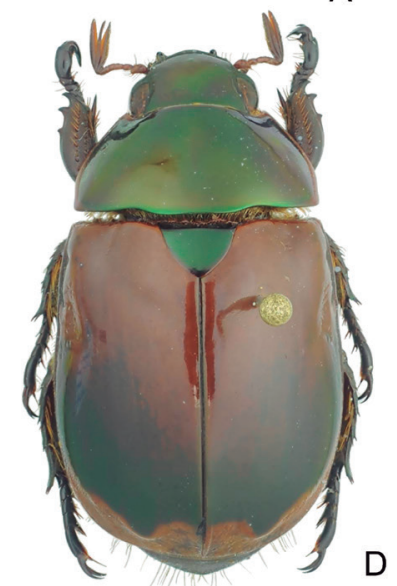

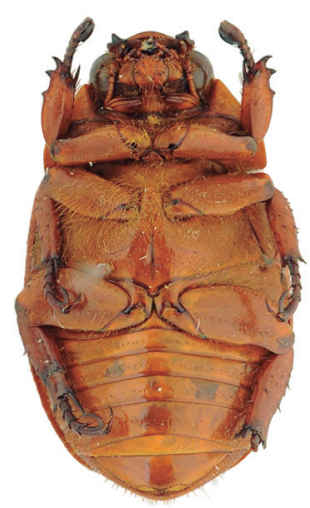

B

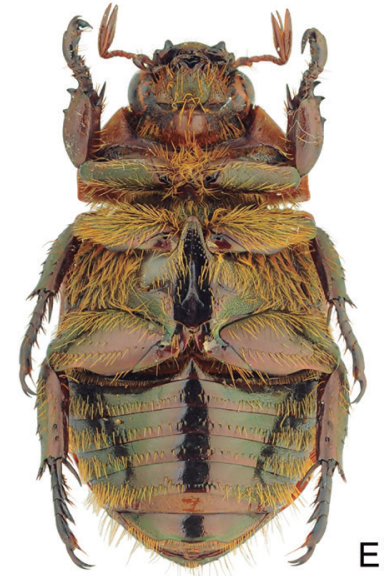

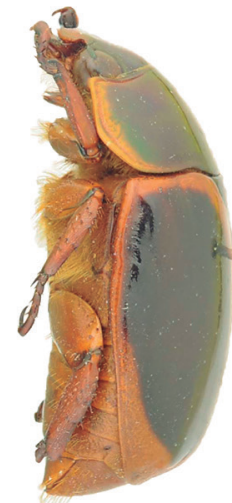

C

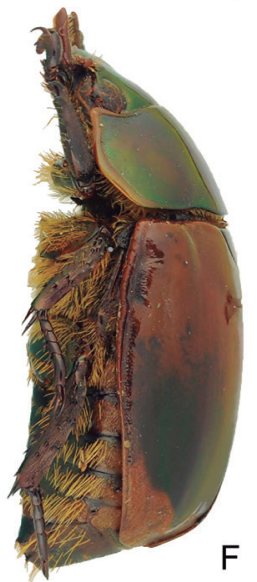

Figure 4. Chlorota species, habitus. (A-C) C. haemorrhoidalis touzoti Soula, 2002 (dorsal, ventral, lateral); (D-F) C. paulistana Ohaus, 1912 (dorsal, ventral, lateral).
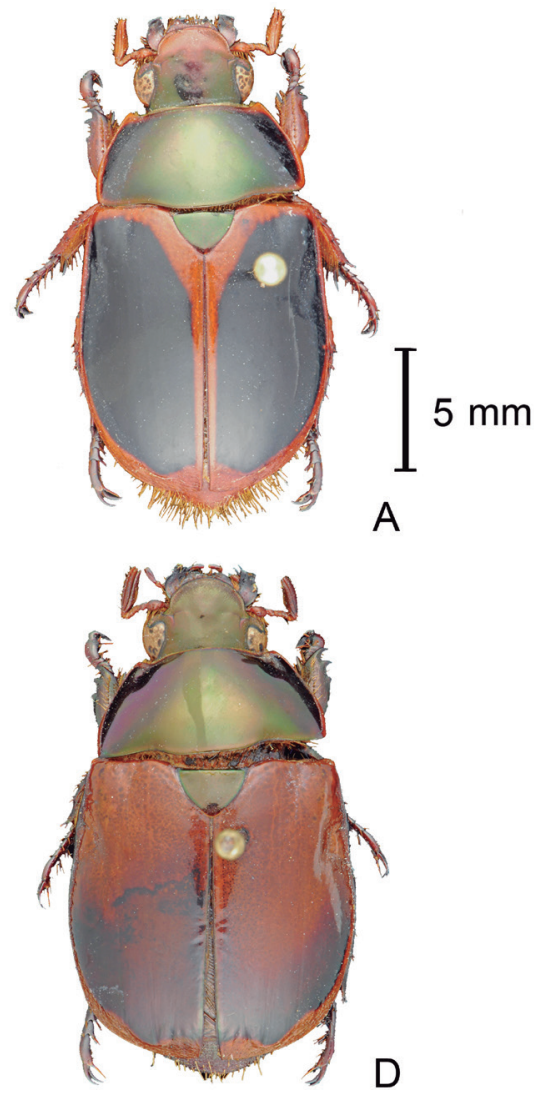
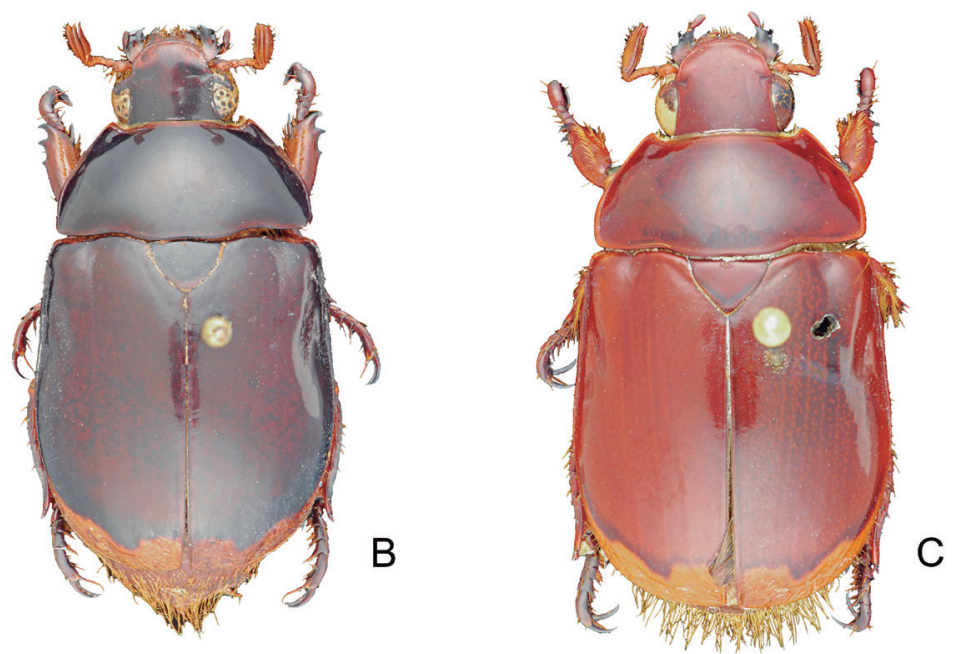

Figure 5. Chlorota species and subspecies, Holotypes from MNHN, dorsal habitus. (A) C. haemorrhoidalis touzoti Soula, 2002; (B) C. surinama lemoulti Soula, 2002; (C) C. surinama egana Soula, 2002; (D) C. parensis Soula, 2002. Images from MNHN. 


\section{Material examined}

Chlorota aulica Burmeister, 1844 (Figs. 3A-C). 1) "C. virens / Cat. Mus. / Brésil", 2) "4197 / 34", 3) "Chlorota / virens, Blanch.", 4) "= aulica Burm. / tris / nob[?] [?] / F Ohaus [?] 1897", 5) "Lectotype / Chlorota / virens Br. / Soula det.", 6) "MNHN EC 1270" (1 \& MNHN). 1) "Brasil, Espírito Santo, Rio Bonito [Santa Maria de Jetibá], 800 m, i.1964 and xii.1963" (1 o', 1 \& CERPE).

Chlorota cuprea Burmeister, 1844 (Figs. 3D-F). New occurrence record: 1) “Brasil, Espírito Santo, Rio Bonito [Santa Maria de Jetibá], 800 m, i.1964 and i.1965 (1 ơ, 1 @ CERPE)".

Chlorota parensis Soula, 2002 (Fig. 5D). 1) "Amazones / Taperinha-Santarem / A.H. Fassl / 1920", 2) "Muséum Paris / ex Coll. / R. Oberthür / 1952", 3) "Holotype / Chlorota / parensis / Soula det. so.", 4) “MNHN / EC 1282" (1 +, MNHN).

Chlorota paulistana Ohaus, 1912 (Figs. 4D-F). 1) "Brasil, Bahia, Porto Seguro, Reserva do Pau Brasil, i.1990 E. \& P. Grossi legs" (1 o", CERPE); 1) "Brasil, Pernambuco, Recife, Mata do Brennand, breed, 12.x.2016. em tronco podre, T. Carvalho \& A. Almeida legs" (1 ơ', CERPE).
Chlorota haemorrhoidalis touzoti Soula, 2002 (Figs. 4A-C, 5-A). New occurrence records: 1) "Brasil, Amazonas, Manaus, RS41 (WWF-INPA), 17.x.1990, J.C. Volotini leg". (1 o", CERPE); 1) "Brasil, Amazonas, Manaus, R. Florestal Adolpho Ducke, 16-20.ix.2010 arm. Malaise, Cordeiro, Grisales, Guedes \& Haseyama legs." (3 o', CERPE); 1)“Brasil, Amazonas, Manaus, Res. ZF2, 23-26.ix.2010 arm. VSR com banana, Cordeiro, Grisales, Guedes \& Haseyama legs" (1 o", 1 \& CERPE); 1) "Obidos Para / BRESIL (XII/94)", 2) "Holotype / Chlorota / touzoti / Soula det. So.", 3) "MNHN / EC1280" (1 o", MNHN).

Chlorota surinama egana Soula, 2002 (Fig. 5C). 1) "Ega”, 2) "Ex-Musaeo / H.W. BATES / 1982", 3) "Muséum Paris / ex Coll. R. Oberthür / 1952", 3) "Holotype Chlorota / surinama egana Sou. / Soula det.", 4) "MNHN / EC1276" (1 o", MNHN).

Chlorota surinama lemouti Soula, 2002 (Fig. 5B). 1) "Amazones / Taperinha-Santarem / A.H. Fassl / 1920", 2) “Muséum Paris / ex Coll. R. Oberthür / 1952", 3) “Holotype / Chlorota / surinama / lemoulti / Soula det. So.", 4) "MNHN / EC1275" (1 o", MNHN).

\section{Key to Brazilian species of Chlorota (adapted from Soula, 2002b)}

1. Mesosternal process extending beyond the mesocoxae; whole body with green metallic colors, green or coppery metallic reflexes, uniform coloration (Group aulica)

- Mesosternal process not extending beyond the mesocoxae; different colors, can present green metallic or coppery reflexes in some parts of the body (Group terminata)

2. Integument predominantly green, sometimes with strong brown or coppery reflections; apex of mesosternal process rounded.

Chlorota aulica Burmeister, 1844

Integument predominantly or with some coppery-brown reflections; apex of mesosternal process suboval. .Chlorota cuprea Burmeister, 1844

3. Elytra and pronotum with lighter borders .... 4

— Elytra lighter than other body parts or not, with or without lighter stains or borders ....................................................................................................... 8

4. Clypeus rounded; apex of the pre-mentum clearly bilobed.

- Clypeus rounded or parabolic; apex of pre-mentum wide rounded.

5. Integument with brown coloration; region near scutellum smooth Chlorota surinama lemoulti Soula, 2002

- Integument with reddish-brown coloration; region near scutellum with a transversal sulcus .Chlorota surinama egana Soula, 2002

6. Clypeus lighter than frons; basal tooth of protibia short and acuminate; elytra with the same color of the body......

- Clypeus and frons brown, or lighter only on apex of the clypeus; basal tooth of protibia very short and almost truncate; elytra darker than the body

Chlorota abdominalis Ohaus, 1926

7. Elytral suture with borders not extending from base to apex .. Chlorota haemorrhoidalis solimoensis Ohaus, 1908

- Elytral suture with borders extending from base to apex Chlorota haemorrhoidalis touzoti Soula, 2002

8. Venter moderately setose, especially on pygidium and abdomen; species from northeast and southeast region of Brazil.

- Venter sparsely setose, especially on pygidium and abdomen; species from northern and mid-north region of Brazil......

9. Right side of apex of paramere with larger pronounced projections; elytra brown

- Right side of apex of paramere with short projections; elytra yellowish brown and apex with brown spots

10. Clypeus rounded; clypeus, frons and elytra slightly punctate

- Clypeus parabolic with acuminate apex; clypeus, frons and elytra strongly punctate

\section{ACKNOWLEDGMENTS}

We would like to thank Prof. Dr. Sônia Casari and Dr. Gabriel Biffi for the invitation to collaborate in this issue. We also thank CAPES (Coordenação de Aperfeiçoamento de
Pessoal de Nível Superior, process number CAPES/Proex 88887.333488/2019-00), Ministério da Ciência, Tecnologia e Inovação (MCTI/CNPq/Universal 2014, process number 449366/2014-6) for financial support, and MNHN for the photos of type specimens used in this paper. 


\section{REFERENCES}

Carvalho, T.G.; Duarte, P.R.M.; Fuhrmann, J. \& Grossi, P.C. 2019. Description of the last larval instar and pupa of Chlorota paulistana Ohaus, 1912. Revista Brasileira de Entomologia, 63(3): 245-249. D0I

Ferreira, A.S.; Almeida, L.M.; Bravo, F. \& Grossi, P.C. 2018. A checklist of Rutelinae MacLeay, 1819 (Coleoptera, Melolonthidae) of Bahia, Brazil. Biota Neotropica, 18(2): e20170476. DOI

Grossi, P.C. \& Vaz-de-Mello, F.Z. 2015. Moronius miguelangeli new genus and new species of Areodina from western Brazil (Melolonthidae, Rutelinae, Rutelini). Dugesiana, 22: 221-226. DOI

Jameson, M.L. 1990. Revision, phylogeny and biogeography of the genera Parabyrsopolis Ohaus and Viridimicus, new genus (Coleoptera: Scarabaeidae: Rutelinae). Coleopterists Bulletin, 44: 377-422.

Krajcik, P.M. 2008. Checklist of Scarabaeoidea of the World: Rutelinae (Coleoptera: Scarabaeidae: Rutelinae). Animma. X: Insecta (Coleoptera), suppl. 4: 1-273.

Moore, M.R.; Jameson, M.L. \& Paucar-Cabrera, A. 2014. Taxonomic and nomenclatural changes in the anticheirine scarabs (Coleoptera: Scarabaeidae: Rutelinae: Rutelini). Insecta Mundi, 0392: 1-20.
Shorthouse, D.P. 2010. SimpleMappr, an online tool to produce publicationquality point maps. Available at: https://www.simplemappr.net. Access in: 17/10/2019.

Soula, M. 2002a. Rutelini 2. In: Les Coléoptères du Nouveau Monde. Canterbury, Hillside Books. v. 26, pt. 1, p. 1-102p.

Soula, M. 2002b. Rutelini 2. In: Les Coléoptères du Nouveau Monde. Canterbury, Hillside Books, v. 26, pt. 2, p. 117-296.

Soula, M. 2005. Rutelini 2. Révision des Anticheirina 3. In: Les Coléoptères du Nouveau Monde. Canterbury, Hillside Books. v. 26, pt. 3, p. $297-409$.

Soula, M. 2006. Les Coléoptères du Nouveau Monde. Rutelini 1. Révision des Pelidnotina 1 et des Lasiocalina. Besoiro, Supplément au Bulletin de liaison de l' Association Entomologique pour la Connaisance de la Fauna Tropicale, 1: 3-176.

Soula, M. 2008. Les Coléoptères du Nouveau Monde. Rutelini 2. Révision des Pelidnotina 2. Besoiro, Supplément au Bulletin de liaison de l'Association Entomologique pour la Connaisance de la Fauna Tropicale, 2: 1-40. 